ОГЛЯД ЛІТЕРАТУРИ

DOI: $10.21802 /$ artm.2019.3.11.99.

УДК 616.14-007.64-046.97

\title{
ОГЛЯД ЕФЕКТИВНОСТІ МОНОТЕРАПЕВТИЧНОГО ТА КОМБІНОВАНОГО ЛІКУВАННЯ ВЕНОЗНИХ ВИРАЗОК
}

\section{А.Ю. Глаголєва, С.І. Саволюк}

\author{
Начіональна медична академія післядипломної освіти імені П.Л. Шупика, кафедра хірургії та \\ судинної хірургії, м. Київ, Україна, \\ ORCID ID: 0000-0003-1256-7277, e-mail:nglagoleva90@gmail.com, \\ ORCID ID: 0000-0001-5406-8228, e-mail: savoluk@meta.ua
}

Резюме. Одним із ускладнень хронічної венозної недостатності нижніх кінцівок, що суттєво погіршують якість життя пацієнтів, є утворення виразкових дефектів. Останні характеризуються повільним, часто неповним загоєнням, утворенням рецидивних виразок. Важливо проводити детальну оцінку як самого дефекту, так і вірогідних системних порушень у пацієнтів з метою планування найбільш ефективної тактики лікування. Для усунення хронічного запального процесу та забезпечення загоєння венозних виразок найчастіше застосовується компресійна терапія, малоінвазивні втручання, такі як склерооблітерація та термічна абляція, традиційні методи хірургічного лікування (стриппінг), дебрідмент та медикаментозне лікування препаратами на основі діосміну/геспередину. Дослідженнями зарубіжних та вітчизняних авторів продемонстрована висока ефективність комбінованого лікування, а саме поєднання застосування компресії (34-46 мм рт.ст.) на нижні кінцівки із мініінвазивними техніками усунення патологічного вено-венозного рефлюксу (у тому числі за допомогою вітчизняної технології ендовенозного біоелектрозварювання), прийомом венотонічних засобів на основі діосміну/геспередину (зокрема препарат «Нормовен») та місцевою обробкою виразкових дефектів. Окрім того, оптимізація раціону харчування, відмова від куріння, зниження маси тіла за наявності ожиріння, корекція супутньої серцево-судинної патології додатково до основного лікування сприяють швидшому загоєнню венозної виразки, підвищенню рівня якості життя пацієнтів та відновленню/збереженню працезданості.

Ключові слова. Венозні виразки, діосмін, компресійний трикотаж, ендовенозне біоелектозварювання.

Вступ. Венозні виразки $є$ широко розповсюдженим видом трофічних розладів нижніх кінцівок, на який страждає до $1 \%$ населення світу. Підвищений тиск у венах, турбулентний потік крові та недостатнє повернення венозної крові до серця через оклюзію або вено-венозний рефлюкс активують запальний процес, запускаючи міграцію лейкоцитів, пошкодження ендотелію, агрегацію тромбоцитів та внутрішньоклітинний набряк [1]. Венозні виразки нижніх кінцівок або застійний дерматит є найбільш важкою формою хронічної венозної недостатності, складаючи близько 80 \% всіх видів виразок вказаної локалізації $[2,3]$.

Старший вік, ожиріння, травми кінцівки в анамнезі, тромбоз глибоких вен та флебіти є основними факторами ризику, що погіршують перебіг венозних виразок [4]. Венозні виразки часто рецидивують, погано загоюються, а в деяких випадках можуть малігнізуватися [5]. Дана патологія вимагає правильної оцінки та ретельної диференційної діагностики для розробки індивідуального плану лікування. Венозні виразки можна діагностувати клінічно на підставі анатомічного розташування, морфологічних характеристик та ряду специфічних змін шкіри, що визначаються візуально. При цьому, важливе значення у деталізації вказаної патології має поглиблене обстеження, що включає визначення кісточково- плечового індексу, доплерографію, кольорове дуплексне сканування, плетизмографію та венографію.

Лікування венозних виразок включає компресійну терапію, малоінвазивні втручання, такі як склерооблітерація та термічна абляція, традиційні методи хірургічного лікування (стриппінг), дебрідмент та медикаментозне лікування препаратам на основі діосміну/геспередину.

При лікуванні венозних виразок основними завданнями $€$ зменшення набряку, прискорення загоєння та запобігання рецидиву. Модифікація раціону харчування, відмова від куріння, зниження ваги, корекція супутньої кардіологічної патології сприяють кращому загоєнню венозної виразки та підвищенню рівня якості життя пацієнтів (клас I, рівень доказу C) [6]. Фізичні вправи, засновані на застосуванні принципу прогресивного опору, та підвищене положення нижніх кінцівок позитивно впливають на загоєння виразок, зменшують больовий синдром та набряки, запобігають рецидиву виразки (клас IIA, рівень доказу В) [7]. Рандомізоване клінічне дослідження 3 12тижневим періодом спостереження продемонструвало суттєве зменшення розміру виразки (на $32 \%, \mathrm{p}=$ $0,34)$ та покращення параметрів функції м'язевої помпи в литках (фракція викиду $\mathrm{p}=0,05)$, залишкова фракція залишкового об'єму $(\mathrm{p}=0,04)$ та діапазону рухів у гомілковоступневому суглобі $(\mathrm{p}=0,01)$ у пацієнтів, які вдома займались фізичними вправами, 
заснованими на принципі прогресивного опору, за спеціальною програмою [8].

Медикаментозне лікування венозних виразок включає системну та місцеву терапію. Із системних засобів найбільш широко застосовуються флеботоніки (переважно препарати на основі діосміну в дозуванні 1000 мг на добу) - це клас препаратів, що зміцнюють стінки судин, підвищують венозний тонус та лімфатичний дренаж і нормалізують проникність капілярів [9]. Дані препарати модулюють адгезію лейкоцитів, підвищують тонус венозної стінки та захищають клітини від гіпоксії [10]. Мета-аналіз Соleridge-Smith et al. показав, що у пацієнтів, які додатково отримували діосмін/геспередин, загоєння виразок відмічалось частіше через 6 місяців (відносне зниження ризику $32 \%$; довірчий інтервал 3-70\%) [11]. Активні метаболіти діосміну максимально накопичуються в усіх шарах стінок як поверхневих, так i глибоких вен нижніх кінцівок, менше - в нирках, печінці, легенях та інших тканинах. Серед інших рослинних флавоноїдів, які чинять капіляростабілізуючу та ангіопротекторну дію, виділяють гесперидин. В Україні при лікуванні варикозної хвороби нижніх кінцівок при хронічній венозній недостатності різного ступеня широко застосовується комплексний препарат «Нормовен», який містить 450 мг діосміну та 50 мг гесперидину. У дослідженні Корсак В.В. та співавт. вивчалось застосування препарату «Нормовен» при патогенетичному лікуванні пацієнтів із варикозною хворобою нижніх кінцівок (C2-С3 за класифікацією СЕАР). Визначалось, що на фоні прийому препарату «Нормовен» протягом 1 місяця після операції спостерігався суттєво менший відсоток пацієнтів із синдромом «важких ніг», набряками, больовим синдромом у порівнянні з групою пацієнтів, які не отримували флеботонічні препарати $(\mathrm{p}<0,05)[12]$. В іншому дослідженні встановлено, що поєднання хірургічного лікування варикозної хвороби й посттромбофлебітичного синдрому із призначенням препарату «Нормовен» дозволяє усунути парестезії у 76,7 \% пацієнтів, больовий синдром - у $77,8 \%$, набряк кінцівок - у 62\%, а також ефективно попередити утворення венозних виразок [13]. На базах кафедри хірургії та судинної хірургії Національної медичної академії імені П.Л. Шупика наразі триває порівняльне дослідження 3 використанням препарату «Нормовен» у комплексному лікуванні пацієнтів з венозними виразками (до 7 см у найбільшому розмірі). Проміжні результати вказують на ефективність застосування даного препарату з огляду на вищу швидкість, більший відсоток повного загоєння венозних виразок та кращу якість життя пацієнтів, які отримували «Нормовен» у комбінації 3 хірургічним лікуванням та носінням компресійного трикотажу III класу компресії (34-46 мм рт.ст.). Оксерутин, екстракт кінського каштану та кальцію добезилат виявились неефективними у лікуванні варикозної хвороби та венозних виразок [14-15]. У одному 3 оглядів Cochrane була продемонстрована ефективність застосування пентоксифіліну в якості додаткового лікування при застосування компресійної терапії щодо швидкості загоєння венозних виразок (відносний ризик, 1,56; 95 \%, довірчий інтервал 1,14-
2,13) та при монотерапії вказаним препаратом (відносний ризик, 2,25; 95 \%, довірчий інтервал 1,493,39) [16].

Рандомізованими дослідженнями доведено, що при лікуванні венозних виразок виправдано застосування статинів, так як дані препарати мають позитивну імуномодулюючу дію, покращують мікросудинну функцію та зменшують оксидативний стрес, тим самим сприяючи загоєнню ран [17]. У дослідженні Raposio E. et al. встановлено, що прийом симвастатину (40 мг) кожного дня сприяв значному прискоренню загоєння венозних виразок ( $<<0,001)$, а також покращенню якості життя пацієнтів $(\mathrm{p}<0,001)$ у порівнянні з плацебо [18].

Для загоєння венозних виразок також застосовуються різні місцеві антибіотики та антисептики, серед яких препарати йоду, сульфадіазин срібла та мупіроцин. Однак згідно з доказовими даними рекомендується застосовувати місцеве протимікробне лікування лише за наявності ознак локальної інфекції [19].

Перев'язки з активними речовинами або без них прискорюють процес загоєння ран у зоні виразки за рахунок регулювання вологообміну та посилення гідратації ураженої ділянки [20]. Окрім того, вони сприяють аутолітичному дебрідменту, зменшенню ексудації та ризику інфікування, а також зменшують больовий синдром. Пов'язку можна застосовувати одночасно із застосуванням компресії, щоб уникнути прилипання синтетичного матеріалу до рани [21]. Для загоєння венозних виразок застосовуються різні види пов'язок, такі як плівки, гідроколоїди, гідрогелі, альгінати та піни [22].

У дослідженнях встановлено, що вакуумтерапія венозних виразок (ВТ) збільшує кровотік, прискорює утворення грануляційної тканини та зменшує набряк у зоні ураження при застосуванні регульованого безперервного або переривчастого тиску. Alkhateep et al. вивчали ефективність вакуумтерапії при венозних виразках у рандомізованому контрольованому дослідженні протягом 3 місяців. У групі, в якій пацієнтам застосовували переміжний негативний тиск при від -100 до 150 мм рт.ст. 3 заміною пов'язки кожні 48-72 год., визначалось суттєве зменшення розмірів виразки та вищий відсоток повністю загоєних виразок у порівнянні з контрольною групою, пацієнтам якої виконувались перев'язки 3 фізіологічним розчином (68 \% випадків загоєння площі виразки більше 90 \% в основній групі проти жодного в групі порівняння) [23].

Компресійна терапія (з тиском 40 мм рт.ст.) є ключовим елементом консервативного лікування венозних виразок, так як вона забезпечує зменшення набряку, усунення венозного рефлексу, покращує загоєння ран та полегшує біль у 30-60\% випадків через 6 місяців та у 70-85\% через 1 рік (клас I, рівень доказу А) [24].

Хірургічне лікування при венозних виразках сприяє загоєнню в $88 \%$ випадків, при цьому рівень рецидивів складає $13 \%$ протягом 10 місяців [1]. Для лікування венозних виразок використовуються пінна склерооблітерація, ендоабляція (лазерна або радіочастотна абляція), субфасціальна ендоскопічна дис- 
секція перфорантних вен (SEPS) та стентування оклюдованих глибоких вен. У дослідженні HarlanderLocke M. et al. було продемонстровано, що абляція неспроможних поверхневих та перфораторних вен у 110 хворих на варикозну хворобу (140 операцій; 74 на поверхневих венах та 66 - на перфорантах) за відсутності ефекту попереднього застосування компресійної терапії забезпечила зменшення розміру виразок та остаточного загоєння [25]. Крім того, було показано, що ендовенозна абляція неспроможних поверхневих та перфорантних вен із паралельним застосуванням компресії зменшує вірогідність рецидиву виразки у порівнянням із ізольованим застосуванням компресійної терапії у пацієнтів із загоєними венозними виразками [26]. Натомість, в огляді Cochrane 2019 року (Lin et al.) достовірних переваг субфасціальної ендоскопічної диссекції перфорантних вен як ізольованого методу або компоненту комбінованої терапії при лікуванні венозних виразок не встановлено [27].

У вітчизняній літературі представлені результати застосування ендовенозного біоелектрозварювання при хронічній венозній недостатності, ускладненій виразкоутворенням нижніх кінцівок. Апарат ЕК300М («Свармед») забезпечує подачу теплової енергії (трансформованої 3 електричної) на спеціалізований ендовенозний інструмент оригінальної конструкції (CEI). Робоча частина являє собою адаптований для пункційного введення біполяр 3 діаметром від 2 до 3 мм та довжиною 5 см, тубус виконаний із полімеру, який забезпечує достатню гнучкість і жорсткість при маневруванні у просвіті вени.

Схема роботи пристрою полягає в наступному. Високочастотний модульований струм, що проходить між полюсів ЗЕІ та крізь провідне середовище, обумовлює його нагрівання протягом робочого циклу (РЦ), що призводить до дегідратації та денатурації білків крові та венозної стінки, що супроводжується зростанням опору. РЦ здійснюється при напрузі від 10 до $100 \mathrm{~B}$, частоті змінного струму 50 500 кГц, з модуляцією частоти від 0,1 до 250 кГц, при опірності тканини від 0,1 до 1000 Ом, при нагріві тканин до $50-75^{\circ} \mathrm{C}$ та глибині поширення тепла 1,5 - 2 мм. Контроль тривалості енерговпливу відбувається автоматично. Розвивається оклюзія неспроможної ділянки вени (стовбура підшкірної вени або перфоранти) і усувається патологічний вено-венозний рефлекс. У всіх пацієнтів, яким застосовувалась описана технологія разом із носінням компресійних панчох III класу компресії, відмічалось загоєння венозних виразок протягом 6 місяців 3 моменту операції [28].

Пінна склерооблітерація у комбінацією із носінням компресійного трикотажу в дослідженні Darvall et al. забезпечила загоєння виразок у $96 \%$ випадків протягом 3 місяців, і лише у двох пацієнтів iз загоєними виразками (7\%) відмічалися рецидиви протягом 12 місяців спостереження [29]. Разом 3 цим, малоінвазивна абляція стовбура підшкірної вени та перфорант $з$ патологічним рефлюксом у поєднанні $з$ компресійною терапією $є$ безпечною опцією, що сприяє прискоренню загоєння активних хронічних венозних виразок [30]. Тим не менш, в огляді Cochrane підкреслюється необхідність проведення якісних рандомізованих контрольованих досліджень та перспективних дослідженнях для остаточного доведення ефективності використання малоінвазивних процедур абляції при лікуванні венозних виразок [31].

Хірургічний дебрідмент, пошарова дерматоліпектомія (shave therapy), стріппінг неспроможних ділянок вен також застосовуються для лікування венозних виразок. Варіанти хірургічного дебрідменту включають автолітичні, хімічні, механічні, хірургічні та біологічні методи [32]. У рандомізованому дослідженні Van Gent WB et al. виявлено значно вищий відсоток загоєння венозних виразок (58,9 проти $39,6 \%, \mathrm{p}=0,007)$ та низьку частоту рецидивів (48,9 проти 94,3\%) при хірургічному лікуванні (комбіноване хірургічне лікування поверхневих та перфоративних вен) порівняно 3 консервативною терапією (компресійний трикотаж) [33]. У систематичному огляді Howard DP et al. при операціях на неспроможних поверхневих венах та консервативній компресійній терапії спостерігаються подібні результати стосовно загоєння виразки, однак рецидиви виразки після хірургічного втручання відмічаються piдше [34]. Також у дослідженні ESCHAR було визначено, що через 24 тижні частота рецидивів виразки зменшилася вдвічі у пацієнтів, які перенесли операцію, незалежно від наявності неспроможності глибоких вен [35].

Висновки та обговорення. Венозні виразки $\epsilon$ складною патологією, яка негативно впливає на якість життя пацієнтів та суттєво знижує працездатність. Для визначення етіології та складання оптимального плану лікування необхідна комплексна оцінка стану здоров'я пацієнта та безпосередньо характеристик кровотоку нижніх кінцівок та самої виразки. Дані високого ступеня доказовості свідчать про те, що найефективнішим підходом у лікуванні венозних виразок $є$ застосування флавоноїдів разом із традиційними методами лікування. Застосування комплексного вітчизняного препарату «Нормовен» на всіх стадіях варикозної хвороби нижніх кінцівок, в тому числі за наявності венозних виразок, дозволяє прискорити їх загоєння та попередити рецидив. Компресійна терапія є основною складовою терапії венозних виразок, однак хірургічне лікування може забезпечити ефективне загоєння/зменшення площі виразки як додатковий метод, а також як додатковий або альтернативний метод за відсутності ефекту від застосування компресії. Ендовенозні малоінвазивні хірургічні методики, конвенційна венектомія та компресійна терапія дають подібні результати щодо темпів загоєння виразки, однак хірургічне лікування забезпечує менший ризик рецидиву. Ведення пацієнтів із венозними виразками повинно бути мультидисциплінарним i включати детальний збір анамнезу, фізикальне та лабораторноінструментальне обстеження, а також застосування новітніх способів лікування 3 належним навчанням 
пацієнтів щодо модифікації харчових звичок та способу життя.

\section{References:}

1. Collins L, Seraj S. Diagnosis and treatment of venous ulcers. Am Fam Physician. 2010;81(8):989-996.

2. O'Donnell TF, Passman MA. Clinical practice guidelines of the Society for Vascular Surgery (SVS) and the American Venous Forum (AVF) - management of venous leg ulcers. Introduction J Vasc Surg. 2014;60(2 Suppl):1S-2S.

3. Agale SV. Chronic leg ulcers: epidemiology, aetiopathogenesis, and management. Ulcers. 2013;2013:1-9. 4) Rai R. Standard guidelines for management of venous leg ulcer. Indian Dermatol Online J. 2014;5(3):408-411. 5. Jindal R, Dekiwadia DB, Krishna PR, et al. EvidenceBased Clinical Practice Points for the Management of Venous Ulcers [published correction appears in Indian $\mathbf{J}$ Surg. 2018 Apr;80(2):183]. Indian J Surg. 2018;80(2):171-182.

6. Zenilman J, Valle MF, Malas MB, et al. Chronic Venous Ulcers: A Comparative Effectiveness Review of Treatment Modalities [Internet]. Rockville (MD): Agency for Healthcare Research and Quality (US); 2013 Dec. (Comparative Effectiveness Reviews, No. 127.) Available from:

https://www.ncbi.nlm.nih.gov/books/NBK179152/

7. Dekiwadia DB, Jindal R, Varghese R, Bedi HS, Padaria S, Patel MD, Agarwal S, Saravanan S, Rao UV, Pinjala R, Singh G. Executive summary: a consensus statement - part I: recommendations for the management of chronic venous disease (CVD) in India and key role of primary care doctors. J Assoc Physicians India. 2016;64(8):53-56

8. O'Brien J, Edwards H, Stewart I, Gibbs H. A homebased progressive resistance exercise programme for patients with venous leg ulcers: a feasibility study. Int Wound J. 2013;10(4):389-396

9. Nicolaides A, Kakkos S, Eklof B, Perrin M, Nelzen O, Neglen P, et al. Management of chronic venous disorders of the lower limbs-guidelines according to scientific evidence. Int Angiol. 2014;33(2):87-208

10. Scallon C, Bell-Syer SE, Aziz Z. Flavonoids for treating venous leg ulcers. Cochrane Database Syst Rev. 2013;5:CD006477

11. Coleridge-Smith P, Lok C, Ramelet AA. Venous leg ulcer: a meta-analysis of adjunctive therapy with micronized purified flavonoid fraction. Eur J Vasc Endovasc Surg. 2005;30(2):198-208. doi: 10.1016/j.ejvs.2005.04.017.

12. Korsak VV, Rusyn VV. Kompleksne likuvannya varykoznoyi khvoroby nyzhnikh kintsivok. Praktychna medytsyna. 2008;5:121-124.

13. Likuvannya khronichnoyi venoznoyi nedostatnosti nyzhnikh kintsivok. Novi al'ternatyvy [Elektronnyy resurs] / PI Nikul'nikov, HH Vlaykov, AA Huch // Krovoobih ta hemostaz. - 2008. - № 1. - S. 76-78.

14. Leach MJ, Pincombe J, Foster GW. Clinical efficacy of horse chestnut seed extract in the treatment of venous ulceration. J Wound Care. 2006;15(4):159-167. doi: 10.12968/jowc.2006.15.4.26898

15. Martinez-Zapata MJ, Moreno RM, Gich I, Urrútia G, Bonfill X. A randomized, double-blind multicentre clini- cal trial comparing the efficacy of calcium dobesilate with placebo in the treatment of chronic venous disease. Eur J Vasc Endovasc Surg. 2008;35(3):358-365. doi: 10.1016/j.ejvs.2007.08.012

16. Jull AB, Arroll B, Parag V, Waters J. Pentoxifylline for treating venous leg ulcers. Cochrane Database Syst Rev. 2012;12:CD001733.

17. Raposio E, Libondi G, Bertozzi N, Grignaffini E, Grieco MP. Effects of topic simvastatin for the treatment of chronic vascular cutaneous ulcers: a pilot study. J Am Coll Clin Wound Spec. 2015;7(1-3):13-18. doi: 10.1016/j.jccw.2016.06.001

18. Evangelista MT, Casintahan MF, Villafuerte LL. Simvastatin as a novel therapeutic agent for venous ulcers: a randomized, double-blind, placebo-controlled trial. $\mathrm{Br} \mathrm{J}$ Dermatol. 2014;170(5):1151-1157. doi: 10.1111/bjd.12883

19. Franks PJ, Barker J, Collier M, Gethin G, Haesler E, Jawien A, Laeuchli S, Mosti G, Probst S, Weller C. Management of patients with venous leg ulcers: challenges and current best practice. J Wound Care. 2016;25(Sup6):S1-S67.

10.12968/jowc.2016.25.Sup6.S1

20. Norman G, Westby MJ, Rithalia AD, Stubbs N, Soares MO, Dumville JC. Dressings and topical agents for treating venous leg ulcers. Cochrane Database Syst Rev. 2018;6(6):CD012583. Published 2018 Jun 15. doi:10.1002/14651858.CD012583.pub2

21. Westby MJ, Norman G, Dumville JC, Stubbs N, Cullum N. Protease-modulating matrix treatments for healing venous leg ulcers. Cochrane Database Syst Rev. 2016;12(12):CD011918. Published 2016 Dec 15. doi:10.1002/14651858.CD011918.pub2

22. Dogra S, Rai R. Venous leg ulcer: topical treatment, dressings and surgical debridement. Indian Dermatol Online J. 2014;5(3):371-973

23. Alkhateep Y, Zaid N, Fareed A. Negative pressure wound therapy for chronic venous ulcer: a randomizedcontrolled study. Egypt J Surg 2018;37:196-9

24. O'Meara S, Cullum N, Nelson EA, Dumville JC. Compression for venous leg ulcers. Cochrane Database Syst Rev. 2012;11:CD00026

25. Harlander-Locke M, Lawrence PF, Alktaifi A, Jimenez JC, Rigberg D, DeRubertis B. The impact of ablation of incompetent superficial and perforator veins on ulcer healing rates. J Vasc Surg. 2012;55(2):458-464. doi: $10.1016 /$ j.jvs.2011.08.054

26. Harlander-Locke M, Lawrence P, Jimenez JC, Rigberg D, DeRubertis B, Gelabert H. Combined treatment with compression therapy and ablation of incompetent superficial and perforating veins reduces ulcer recurrence in patients with CEAP 5 venous disease. J Vasc Surg. 2012;55(2):446-450. doi: 10.1016/j.jvs.2011.08.009

27. Lin ZC, Loveland PM, Johnston RV, Bruce M, Weller CD. Subfascial endoscopic perforator surgery (SEPS) for treating venous leg ulcers. Cochrane Database Syst Rev. 2019 Mar 3;3:CD012164

28. Horbovets'VS, Savolyuk SI, Dyadyk OO, Hvozdyak MM, Herashchenko RA Rozrobka ta pershyy dosvid zastosuvannya avtomatychnoho rezhymu endovenoznoho elektrozvaryuvannya v likuvanni varykoznoyi khvoroby nyzhnikh kintsivok. «Art of medicine». 2018; 4(8): 3543 . 
29. Darvall KA, Bate GR, Adam DJ, Silverman SH, Bradbury AW. Ultrasound-guided foam sclerotherapy for the treatment of chronic venous ulceration: a preliminary study. Eur J Vasc Endovasc Surg. 2009;38(6):764-769. doi: 10.1016/j.ejvs.2009.05.027

30. Alden PB, Lips EM, Zimmerman KP, Garberich RF, Rizvi AZ, Tretinyak AS, Alexander JQ, Dorr KM, Hutchinson M, Isakson SL. Chronic venous ulcer: minimally invasive treatment of superficial axial and perforator vein reflux speeds healing and reduces recurrence. Ann Vasc Surg. 2013;27(1):75-83. doi: 10.1016/j.avsg.2012.06.002

31. Samuel N, Carradice D, Wallace T, Smith GE, Chetter IC. Endovenous thermal ablation for healing venous ulcers and preventing recurrence. Cochrane Database Syst Rev (10):CD009494

32. Dogra S, Sarangal R. Summary of recommendations for leg ulcers. Indian Dermatol Online J. 2014;5(3):400 407. doi: 10.4103/2229-5178.137829.

33. Van Gent WB, Catarinella FS, Lam YL, Nieman FH, Toonder IM, van der Ham AC, et al. Conservative versus surgical treatment of venous leg ulcers: 10 -year follow up of a randomized, multicenter trial. Phlebology. 2015;30(1 suppl):35-41.

$10.1177 / 0268355514568848$

34. Howard DP, Howard A, Kothari A, Wales L, Guest $\mathrm{M}$, Davies AH. The role of superficial venous surgery in the management of venous ulcers: a systematic review. Eur J Vasc Endovasc Surg. 2008;36(4):458-465. doi: 10.1016/j.ejvs.2008.06.013.

35. Wright DD. The ESCHAR trial: should it change practice? Perspect Vasc Surg Endovasc Ther. 2009;21(2):69-72. doi: 10.1177/1531003509337156

\section{УДК 616.14-007.64-046.97 \\ ОБЗОР ЭФФЕКТИВНОСТИ МОНОТЕРАПЕВ- ТИЧЕСКОГО И КОМБИНИРОВАННОГО ЛЕЧЕНИЯ ВЕНОЗНЫХ ЯЗВ}

\section{А.Ю. Глаголева, С.И. Саволюк}

Наџиональная медицинская академия последипломного образования имени П.Л. Шупика, кафедра хирургии и сосудистой хирургии, г. Киев, Украина, ORCID ID: 0000-0003-1256-7277, e-mail:nglagoleva90@gmail.com, ORCID ID: 0000-0001-5406-8228, e-mail:savoluk@meta.ua

Резюме. Одним из осложнений хронической венозной недостаточности нижних конечностей, существенно ухудшающих качество жизни пациентов, является образование язвенных дефектов. Последние характеризуются медленным, часто неполным заживлением, образованием рецидивирующих язв. Важно проводить тщательную оценку как самого дефекта, так и возможных системных нарушений у пациентов с целью планирования наиболее эффективной тактики лечения. Для устранения хронического воспалительного процесса и обеспечения заживления венозных язв чаще всего применяется компрессионная терапия, малоинвазивные вмешательства, такие как склерооблитерация и термическая абляция, традиционные методы хирургического лечения (стриппинг), дебридмент и медикаментозное лечение препаратами на основе флавоноидов. Исследованиями зарубежных и отечественных авторов продемонстрирована высокая эффективность комбинированного лечения, а именно сочетания применения компрессии (34-46 мм рт.ст.) на нижние конечности с миниинвазивными техниками устранения патологического веновенозного рефлюкса (в т.ч. с помощью отечественной технологии эндовенозного биоэлектросваривания), приемом венотонических средств на основе диосмина/геспередина (в частности препарат «Нормовен») и местной обработкой язвенных дефектов. Кроме того, оптимизация рациона питания, отказ от курения, снижение массы тела при наличии ожирения, коррекция сопутствующей сердечно-сосудистой патологии дополнительно к основному лечению способствуют более быстрому заживлению венозной язвы, повышению качества жизни пациентов и восстановлению/сохранению трудоспособности.

Ключевые слова: венозные язвы, диосмин, компрессионный трикотаж, эндовенозное биоэлектросваривание.

\section{UDC 616.14-007.64-046.97 \\ A REVIEW OF EFFECTIVENESS OF MONOTHERAPEUTIC AND COMBINED TREATMENT OF VENOUS ULCERS}

A.Yu. Glagolieva, S.I. Savoliuk

National Medical Academy of Postgraduate Education named after P.L. Shupika, Department of Surgery and Vascular Surgery, Kiev, Ukraine,

ORCID ID: 0000-0003-1256-7277,

e-mail:nglagoleva90@gmail.com,

ORCID ID: 0000-0001-5406-8228,

e-mail:savoluk@meta.ua

\begin{abstract}
Venous ulcers develop as a complication of chronic venous insufficiency of the lower extremities, which significantly impair the quality of life of patients. The mentioned tissue defects are characterized by slow, frequently incomplete healing, formation of recurrent ulcers. It is important to carry out a detailed assessment of both the defect itself and possible systemic disorders in patients in order to work out the most effective treatment tactics. Compression therapy, minimally invasive interventions, such as scleroobliteration and thermal ablation, traditional methods of surgical treatment (stripping), debridement, and diospin/hesperidine-based venotonics are conventionaly used to reduce chronic inflammation and provide healing of venous ulcers. Compression therapy has been proved to be a major component of venous ulcer therapy, however, surgical treatment can provide effective healing/downsizing of the ulcer area as an additional method or as an alternative method in the absence of the effect of compression. Minimally invasive
\end{abstract}


surgical techniques, stripping with traditional venectomy give similar results regarding the ulcer healing rates, but surgical treatment offers a lower risk of recurrence. Studies of foreign and Ukrainian authors have demonstrated the high effectiveness of combined treatment, that includes the combination of compression (34-46 mm $\mathrm{Hg}$ ) applied to the lower extremities with minimally invasive techniques for the elimination of pathological venous reflux, prescription of venotonic diospin/hesperidine agents ("Normoven" in particular) and local treatment of ulcerative defects. The use of endovenous biowelding technology (EK300M; "Svarmed", Ukraine) in automatic mode with originally designed intravascular device has shown promising results regarding venous ulcer management. All patients, who received treatment with the technology described above together with the wearing of III grade compression stockings, a significant healing progress on the ulcer sites was noted during 6 months after surgery. A comparative study on the use of "Normoven" in the complex treatment of patients with venous ulcers (up to $7 \mathrm{~cm}$ in size) is being conducted by the Department of Surgery and Vascular Surgery of Shupyk National Medical Academy. The interim results demonstrate a higher rate, a greater percentage of completely healed venous ulcers, and a better quality of life for patients treated with "Normoven" in combination with surgical treatment and grade III compression stockings. Negative pressure therapy is regarded as a promising option by certain authors as it increases blood flow, accelerates granulation tissue formation and reduces swelling in the ulcer area. Moreover, dietary regulation, smoking cessation, weight loss in case of obesity, correction of concomitant cardiovascular pathology in addition to the main treatment contributes to the faster healing of venous ulcers resulting in the improved quality of life of the patients and restoration/maintenance of working capacity.

Keywords: venous ulcers, diosmin, compression stockings, endovenous biowelding.

Стаття надійшла в редакцію 14.09.2019 р. 